\title{
Impact of Climate Change on Biodiversity Loss and Extinction of Endemic plants of Arid Land Mountains
}

\section{Ali El-Keblawy}

Department of Applied Biology, Faculty of Science, Sharjah University, P.O. Box 27272, Sharjah, UAE

Climate is the fundamental factor that determines different stages of the organism life-cycle, such as plant germination and flowering. It can severely alter habitats and food sources for animals, and ultimately, could have significant impacts on biodiversity of species and ecosystems around the world [1,2]. Global climate change is often considered as one of the major factors causing biodiversity loss. Over the past 100 years, the global average temperature has increased by approximately $0.6^{\circ} \mathrm{C}$ and is projected to continue to rise at a rapid rate [3]. In an extensive literature survey, Parmesan [4] revealed 866 peer-reviewed papers that documented changes through time in species or systems that could, in whole or in part, be attributed to climate change. Observations of range boundary shifts are consistent with the hypothesis that climate contributes to, but is not the sole determinant of, the position of the range boundaries of the majority of terrestrial animal species [5]. Similarly, Root et al. [3] gathered information on species and global warming from 143 studies and their analyses revealed a consistent shift to lower temperatures in species ranging from molluscs to mammals and from grasses to trees.

Range-restricted species, particularly polar and mountaintop species, show severe range contractions [4]. Parmesan and Yohe [6] compiled studies on many species, including alpine herbs, birds, and butterflies, and found an average poleward shift of $6.1 \mathrm{~km}$ per decade. In addition, Thomas [5] analyzed the frequencies with which species have responded to climate change by shifting their range boundaries. For the majority of species, boundaries shifted in a direction that is concordant with being a response to climate change; $84 \%$ of all species have expanded in a polewards direction as the climate has warmed [5]. Parmesan [4] provided evidence that woody plants at their upper altitudinal range boundaries have already responded to global warming by dispersing to higher elevations.

Mountains harbor a unique and large portion of the world's biodiversity. Mountains ecosystems are often endemic, because many species remain isolated at high elevations compared to lowland vegetation communities that can occupy climatic niches spread over wider latitudinal belts [7]. Their geographical isolation, limited range size and unique environmental adaptations make montane species potentially the most threatened under impeding climate change [8]. Because endemic species often show narrow altitudinal distribution patterns they are more threatened [9]. Mountains are not only susceptible to the impacts of a rapidly changing climate [10], but provide interesting locations for the early detection and study of the signals of climatic change and its impacts on hydrological, ecological, and societal systems [7]. The high-altitude ecosystems are largely controlled by climatic constraints, and many plants occur close to their climatic limits of survival.

It has been reported that mountain biota will move upwards as a result of global climate warming $[4,9,11]$. For example, advances of treelines upwards have been shown from several mountain systems around the world [12]. In addition, Kelly and Goulden [11] reported that the average elevation of the dominant plant species rose by $\approx 65 \mathrm{~m}$ during 30 years in a 2,314-m elevation gradient in Southern California's Santa Rosa Mountains. They attributed this shift to changes in regional climate. Similarly, subalpine forests have shifted upwards by $60-80 \mathrm{~m}$ in the Southern Urals during the last 70 years and by $20-40 \mathrm{~m}$ in the Polar Urals during the last 35 years [13]. Furthermore, across 26 mountains in Switzerland, alpine flora has expanded toward the summits since the plots were first censused in the 1940 [9].

The Hajar Mountains in the eastern Arabia (Northern Oman and the eastern UAE) run parallel to the coast of the Gulf of Oman for a distance of more than $600 \mathrm{~km}$. These Mountains are structurally part of the arid mountain chain which extend eastward and southward from Cyprus into Hatay and Syria, along the Turkish- Iranian border southeast through Kermanshah and Neyriz in Iran and finally across the Arabian Gulf into Oman [14]. The Hajar Mountains are divided broadly into Al-Hajar ash-Sharqi and Al-Hajar al-Gharbi (the Eastern and Western Hajar, situated respectively to the east and west of the Jebel Akhdar range) and comprise various smaller ranges and massifs which have independent local names, e.g. Jebel Akhdar, Jebel BaniJabr, Jebel Kawr, Jebel Aswad, Jebel Asfar, Jebel Abyadh, Saih). The Musandam peninsula mountain (Ru'us al-Jibal) is located to the north of Hajar Mountain and is geologically and geographically distinct from the mountains to the south [15].

The Ru'us al-Jibal and their outwash plains effectively constitute the north-eastern boundary of the hyper-arid sand desert of the Empty Quarter; temperatures are high and rainfall is low. There are two basic seasons: a prolonged hot, dry summer from May through October, and a mild to warm winter, with occasional rain, from November through April. Monthly mean maximum temperatures in summer are in the range of $41-45^{\circ} \mathrm{C}$, but monthly mean minimum temperatures in winter are c. $12-15^{\circ} \mathrm{C}$. Temperatures at mountain elevations are relatively lower, compared to above. Frost is unknown in coastal areas but frost or light snowfall can occur as an exceptional event at the highest elevations in the Ru'us al-Jibal, above c.1700 m [15].

The peak of the most recent glaciation in the eastern Arabia occurred at c.17,000-18,000 BP. At that time, sea level was about 120 $\mathrm{m}$ lower than at present and the Arabian Gulf was completely dry, with the shoreline outside the Strait of Hormuz [14,16]. This allowed free dispersal of plants and animals between the Arabia and southern Iran and the Makran region (encompassing south-eastern Iran and the southern part of the province of Baluchistan in south-western

*Corresponding author: Ali El-Keblawy, Department of Applied Biology, Faculty of Science, Sharjah University, P.O. Box 27272, Sharjah, UAE, Tel: +971 50 5432065; E-mail: akeblawy@sharjah.ac.ae, akeblawy@gmail.com

Received February 10, 2014; Accepted February 10, 2014; Published February 17,2014

Citation: El-Keblawy A (2014) Impact of Climate Change on Biodiversity Loss and Extinction of Endemic plants of Arid Land Mountains. J Biodivers Endanger Species 2: 120. doi: 10.4172/2332-2543.1000120

Copyright: ( 2014 El-Keblawy A. This is an open-access article distributed under the terms of the Creative Commons Attribution License, which permits unrestricted use, distribution, and reproduction in any medium, provided the original author and source are credited. 
Pakistan). The similarity of the flora of the Hajar Mountains, especially the cooler Ru'us al-Jibal, to that of southern Iran and the Makran region has been recognized by many authors $[17,18]$, several of the most common species of the Ru'us al-Jibal are more common in Iran than they are elsewhere in Arabia [15].

Climatically, the initial retreat from the glacial maximum was accompanied in Eastern Arabia by a period of extreme aridity from c.17,000-11,000 BP [16]. This indicates that overlapped flora between Eastern Arabia and the southern Iran and the Makran region have separated before 11,000 years. As the temperature increased greatly in the Eastern Arabia during that time, many of the species might extinct. Other more sensitive species, however, retreated to the highest elevations of Hajar Mountain (e.g., Ru'us al-Jibal). The expected increase in the global temperatures on the high mountains of the eastern Arabia would negatively impact these temperature sensitive species of the Iranian origin.

The northern mountains of Oman are classified as a local centre of plant endemism in the eastern Arabia [19,20]. For example, the Jabal al Akhdar massif in the Hajar Mountains of northern Oman hosts about $33 \%$ of Oman's 1200 species of vascular plants, of which 14 taxa are endemic to Oman [20]. In addition, The Eastern Hajar Mountains are unique in the distribution of the endemic tree Prunusarabica (Oliv.) Meikle. Elsewhere, P. arabica occur in southern Iran, Baluchistan, Iraq, north-western Saudi Arabia and Jordan to Turkey [18].

A total of 75 species are locally endemics on the high mountains of the Ru'us al-Jibal. Those species are confined to the Ru'us al-Jibal in the Eastern Arabia, [15]. Approximately $80 \%$ of these species could be founded at medium or high elevations (above $700 \mathrm{~m}$ ). This emphasizes the distinctiveness of the flora of the Ru'us al-Jibal and, consequently, the importance of their conservation through the conservation of the whole landscapes and ecosystems. The majorities of the most common and less common species have the centers of their range in Iran or neighbouring areas of Central Asia. The common species include Artemisia sieberi, Astragalus fasciculifolius, Centaurea wendelboi, Convolvulus acanthocladus, Cymbopogon jwarancusa, Ephedra pachyclada, Jureniaberardioides, Prunusarabica and Teucrium stocksianum and the less common species include Aegilops kotschyi, Dianthus crinitus, Leontice leontopetalum and Salvia mirzayanii $[18,21,22]$.

In regions where climatic change may lead to warmer and drier conditions, mountain vegetation could suffer more as a result of increased evapotranspiration. This is most likely to occur in mountain climates under the influence of continental and Mediterranean regimes [7]. This is clear for Juniperus excelsa, subsp, polycarpos in open woodland in the central range of the Western Hajar Mountains. This species is present from $2100 \mathrm{~m}$ to the summit at $3000 \mathrm{~m}$ [23]. Below $2400 \mathrm{~m}$, the juniper trees are either dead or in very poor condition and regeneration is virtually absent [24]. The juniper woodlands of Oman are unique to the Arabian Peninsula, present elsewhere in the highlands of southern Iran, Baluchistan and Turkey. Juniper would be one of the most threaten species if temperature increased up.

The negative impacts of global warming on biodiversity at all levels mean that ecologists must quickly develop conservation strategies. A major role of conservation planning is to design reserve networks that protect biodiversity in situ [25]. For example, maintaining or enhancing the habitat heterogeneity would provide endangered species with microhabitats that could protect them from the elevated temperature, especially in arid regions. For example, deep narrow gorges played a significant role in marinating Moringa peregrina under the harsh conditions of high temperatures and low rainfalls in its northwestern range edge at Hajar Mountains in the eastern Arabia (El-Keblawy and Khedr, submitted for publication). The gorges are shaded most of the day. Shading would reduce the amount of received solar radiation and hence reduce the rate of evapotranspiration. Similarly, the two trees Pistacia khinjuk and Cordia sp. aff. Quercifolia of Hajar Mountains are both represented by fewer individuals and their presence could be attributed to their protection in cliffs or ledges [15].

Global warming will negatively affected species growing at high elevations of Hajar Mountains. The extinction of local endemic plants from high Hajar Mountains does not mean a complete extinction from the globe; they will be surviving in their cooler central range in southern Iran and the Makran region. However, the real problem will be for the species that are exclusively endemic for the region. Five species endemic to Eastern Arabian species are found in Ru'us Al Gabal. These are Desmidorchis arabica, Echinops erinaceus, Pulicariaedmondsonii, Pteropyrum scoparium and Stipa mandavillei. The extinction of any of these species means a loss of a genetic resource from the globe. Special ex situ conservation program should be set for such species. This includes, but not limited to, the conservation of their seeds and DNA in gene banks [26].

\section{References}

1. Hui D (2013) Global Climate Change and Biodiversity: Issues and Future Research. J Biodivers Endanger Species 1: 1-2

2. Uddin MJ, Mohiuddin ASM, Hossain ST, Hakim A (2013) Eco-environmental Changes of Wetland Resources of Hakalukihaor in Bangladesh Using GIS Technology. J Biodivers Endanger Species 1: 1-4.

3. Root TL, Price JT, Hall KR, Schneider SH, Rosenzweig C, et al. (2003) Fingerprints of global warming on wild animals and plants. Nature 421: 57-60.

4. Parmesan C (2006) Ecological and evolutionary responses to recent climate change. Ann Rev Ecol EvolSyst 37: 637-669.

5. Thomas CD (2010) Climate, climate change and range boundaries. Divers Distrib 16: 488-495.

6. Parmesan C, Yohe G (2003) A globally coherent fingerprint of climate change impacts across natural systems. Nature 421: 37-42.

7. Beniston M (2003) Climatic changes in mountain regions: a review of possible impacts. Climatic change 59: 5-31.

8. La Sorte FA, Jetz W (2010) Projected range contractions of montane biodiversity under global warming. Proceedings of the Royal Society B: Biological Sciences 277: $3401-3410$

9. Grabherr G, Gottfried M, Pauli H (1994) Climate effects on mountain plants Nature 369: 448

10. Nogués-Bravo D, Araújo MB, Errea MP, Martínez-Rica JP (2007) Exposure of global mountain systems to climate warming during the 21st century. Glob Environ Change 17: 420-42.

11. Kelly AE, Goulden ML (2008) Rapid shifts in plant distribution with recent climate change. Proceedings of the National Academy of Sciences 105: 1182311826 .

12. Pauli H, Gottfried M, Reiter K, Klettner C, Grabherr G (2007) Signals of range expansions and contractions of vascular plants in the high Alps: observations (1994-2004) at the GLORIA master site Schrankogel, Tyrol, Austria. Glob Change Biol 13: 147-156.

13. Moiseev PA, Shiyatov SG (2003) Vegetation dynamics at the treelineecotone in the Ural highlands, Russia. Ecological Studies 167: 423-435.

14. Glennie KW (2005) The geology of the Oman Mountains: an outline of their origin. Bucks: Scientific Press Ltd, UK.

15. Feulner GR (2011) The flora of the Ru'us al-Jibal -the mountains of the Musandam Peninsula: An annotated checklist and selected observations. Tribulus19: 4-153. 
Citation: El-Keblawy A (2014) Impact of Climate Change on Biodiversity Loss and Extinction of Endemic plants of Arid Land Mountains. J Biodivers Endanger Species 2: 120. doi: 10.4172/2332-2543.1000120

Page 3 of 3

16. Parker AG, Eckersley L, Smith MM, Goudie AS, Stokes S, et al. (2004) Holocene vegetation dynamics in the northeastern Rub' al-Khali desert, Arabian Peninsula: a pollen, phytolith and carbon isotope study. J Quaternary Sci19: 665-676.

17. Kürschner H (1986) Omanisch-MakranischeDisjunktionenEinBeitragzurpflanz engeographischenStellung und zu den florengenetischenBeziehungenOmans. Bot JahrbSyst106: 541-562.

18. Ghazanfar SA (1998) Status of the flora and plant conservation in the Sultanate of Oman. BiolConserv85: 287-295.

19. Miller AG, Nyberg JA (1991) Patterns of endemism in Arabia. In: Contributionesselectaeadflorametvegetationemorientis: proceedings of the Third Plant Life of southwest Asia Symposium, Berlin, Germay.

20. Patzelt A (2008) Oman Plant Red Data Book. Diwan of Royal Court, Office for Conservation of the Environment, Muscat, Sultanate of Oman.
21. Zohary M (1963) On the geobotanical structure of Iran. Bull Res Counc Isi- IID, Supplement 1-113.

22. Mandaville JP (1984) Studies in the Flora of Arabia XI: Some Historical and Geographical Aspects of a Principal Floristic Frontier. Notes from the Royal Botanical Garden, Edinburgh 42: 1-15.

23. Ghazanfar SA (1991) Vegetation Structure and Phytogeography of Jebe Shams, an arid mountain in Oman. J Biogeogr18: 299-309.

24. Gardner AS, Fisher M (1996) The distribution and status of the montane juniper woodlands of Oman. J Biogeogr 23: 791-803.

25. Bellard C, Bertelsmeier C, Leadley P, Thuiller W, Courchamp F (2012) Impacts of climate change on the future of biodiversity. Ecollett 15: 365-377.

26. Gairola S, Mahmoud T, Bhatt A, El-Keblawy AA (2013) Importance of seed banking and herbarium collections in biodiversity conservation and research: new initiative in the United Arab Emirates. CurrSci India 105: 1048-50. 